\title{
IDENTIFICATION OF THE CAUSATIVE AGENT OF CUTANEOUS LEISHMANIASIS in Chichaoua Province, Morocco
}

\author{
RHAJAOUI M.*, SEBTI F.*, FELLAH H.*, ALAM M.Z.**, NASEREDDIN A.***, ABBASI I.*** \& SCHÖNIAN G.**
}

\section{Summary:}

Cutaneous leishmaniasis (CL) in Morocco is caused by three species, Leishmania major, L. tropica and L. infantum. CL has been known in Chichaoua province since 2000. Using DNA extracted from microscopic slides and parasite cultures, collected in the years 2006 and 2009, we identified for the first time L. tropica as the causative agent of $C L$ in this region. Species identification was achieved by performing the ITS1-PCR-RFLP approach. By using this method it was possible to identify parasites in Giemsa stained slides containing less than five parasites per oil-immersion field even they were conserved for up to four months.

KEY WORDS: leishmaniasis, Leishmania tropica, ITS1-PCR, Morocco.
Résumé : IDENTIFICATION DE L'AGENT CAUSAL DE LA LEISHMANIOSE CUtANÉE DANS LA PROVINCE DE CHICHAOUA, AU MAROC

La leishmaniose cutanée (LC) dans la province de Chichaoua est connue depuis l'an 2000. Cette étude montre pour la première fois l'espèce parasitaire circulante dans cette province. L'identité du parasite a été déterminée sur des lames colorées et des cultures de parasites en utilisant I'ITS1-PCR, suivie de la digestion par l'enzyme Haell. Le résultat a montré que Leishmania tropica est l'agent responsable de la $L C$. Par ailleurs, une corrélation entre le nombre de parasites par lame et la positivité du test moléculaire a été réalisée et a montré que I'ITS1-PCR permet d'identifier des parasites dans les lames colorées au Giemsa contenant moins de cinq parasites par champs et même si elles étaient conservées jusqu'à quatre mois.

MOTS-CLÉS : leishmaniose, Leishmania tropica, ITS1-PCR, Maroc.
$I^{n}$ n Morocco, three species of Leishmania causing human cutaneous leishmaniasis (CL) are endemic (Rhajaoui, 2010). Leishmania major, responsible for zoonotic CL was localized in areas south of the Atlas Mountains (Rioux et al., 1986) where regular epidemics with more than 2,000 cases were reported (Ministère de la Santé, 2007). In the north of the country, some cases of CL due to L. infantum were observed (Rhajaoui et al., 2007). CL caused by $L$. tropica has been reported and well documented (Marty et al., 1989; Guessouss-Idrissi et al., 1997). In Chichaoua province, first cases of CL were recorded in 2000 and it was considered as emerging epidemic focus (Ministère de Santé, 2001). It has been suggested that the disease there was caused by L. tropica and that transmission was by Phlebotomus sergenti (Guernaoui et al., 2005). In this study, we have applied the ITS1 PCR-RFLP assay (Schönian et al., 2003) to samples collected in the years 2006 and 2009 and showed for

\footnotetext{
* Département de parasitologie, Institut National d'Hygiène, Rabat, Morocco.

** Institut fuer Mikrobiologie und Hygiene, Charité Universitaetsmedizin, Berlin, Germany.

**:* Department of Biology, University Al-Quds, Jerusalem, Palestine. Correspondence: Mohamed Rhajaoui, Département de Parasitologie, Institut National d'Hygiène, POB 769, Avenue Ibn Batouta, 11400, Rabat - Agdal, Rabat, Morocco.

Tel.: (212) 537771902 - Fax: (212) 537772067

E-mail: rhajaouimed@yahoo.fr
}

the first time that the causative agent of CL in Chichaoua province is indeed L. tropica. The capacity of the ITS1-PCR to identify parasite in different slides with different parasite burden was also evaluated.

\section{MATERIALS AND METHODS}

\section{CASE DETECTION}

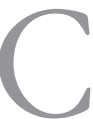

hichaoua province located at $460 \mathrm{~km}$ southern of Rabat covers an area of $7,120 \mathrm{~km} 2$ with altitude ranging from 322 to $1,446 \mathrm{~m}$ above sea level. The vegetation is rare and mainly dominated by jujube plant, olive, carob and almond trees (Guernaoui et al., 2005).

In 2006, 14 positive slides were obtained by dermal scraping of the active indurate margins of the lesions of 14 patients and were smeared on a slide for staining with Giemsa and examined microscopically for presence of amastigotes. Subsequently, Leishmania parasites were successfully cultured in NNN medium for the same 14 patients.

Three years later, in 2009, 34 slides from new cases were confirmed by microscopy as CL. After four months of isolation, the 34 slides were divided into four groups according to the average number of amastigotes counted in 10 oil-immesion fields (OIF) scanned 
randomly by two different blinded persons using the same light microscopy. The quantitative grading of parasitic density in slides is shown in Table I.

\section{MOLECULAR IDENTIFICATION}

This analysis was performed for 48 Leishmania positive slides collected in 2006 and 2009 and 14 cultures maintained in NNN medium. Briefly, DNA was extracted from cultured parasites or positive slides using a phenol chloroform DNA extraction protocol (Meredith et al., 1993, El Tai et al., 2000), the internal transcribed spacer (ITS1) of the ribosomal RNA gene region was amplified and the PCR product was subjected to digestion with endonuclease HaeIII. The entire RFLP product was loaded on agarose gels and analysed as previously described (Schönian et al., 2003; Al-Jawabreh et al., 2004). Reference strains of $L$. tropica (MHOM/AZ/1974/SAF-K27), L. major (MHOM/ IL/1967/Jericho) and L. infantum (MHOM/TN/1980/ IPT1) were used for comparison.

\section{RESULTS}

T he Leishmania parasites in all clinical samples and cultures analysed in this study were identified as L. tropica by their typical restriction profiles (Fig. 1). ITS1 PCR produced one single band, which was $300 \mathrm{bp}$ in size. The RFLP analysis revealed two fragments (185 and $57 \mathrm{bp}$ ), which were specific for $L$. tropica as previously described (Schönian et al., 2003). Furthermore, it could be shown that the ITS1PCR-RFLP assay can detect and identify parasites in Giemsa stained slides containing less than five parasites per oil-immersion field.

\section{DISCUSSION}

his study provides the first direct evidence that CL in Chichaoua region is caused by L. tropica.

_ Previous studies on leishmaniasis in this area have described the region as a focus of CL due to L. tropica solely based on epidemiological and clinical aspects (Guernaoui et al., 2005). In fact, the clinical symptoms of CL were similar to those seen in foci of L. tropica in Taza and Zouagha My Yacoub, and differed clearly, both in form and size, from lesions observed in zoonotic leishmaniasis due to L. major identified in CL foci in southern Morocco. However, geographical origin of the parasites is an inadequate criterion in non-endemic areas as well as endemic regions where multiple species of Leishmania may coexist. Similarly, identification of the infecting species

\begin{tabular}{lcc}
\hline Group & Number of slides & $\begin{array}{c}\text { Average number } \\
\text { of amastigotes per oIF }\end{array}$ \\
\hline G1 & 10 & $>100$ \\
G2 & 8 & $50-100$ \\
G3 & 8 & $10-<50$ \\
G4 & 5 & $5-10$ \\
& 3 & $<5$ \\
\hline
\end{tabular}

Table I. - Quantitative grading of Leishmania amastigotes using stained slides and light microscopy.

based on clinical symptoms can be problematic, since several species cause both visceral and cutaneous disease (Rhajaoui, 2010; Schönian et al., 2003). Thus, as symptoms can vary and may be confused with other etiologic agents, diagnostic confirmation of Leishmania parasite is mandatory. Moreover, it was useful to identify the parasite circulating in Chichaoua region in 2006 and 2009 in order to see if L. tropica is indeed and the only causative agent for $\mathrm{CL}$ in this region.

As the risk patterns for CL have changed recently in several countries (Mihoubi et al., 2008), the observation of L. tropica species from cutaneous lesions of patients living in the Chichaoua area suggests a modification of the epidemiology of CL in Morocco.

The emergence of CL due to L. tropica as an increasingly important public health problem in Morocco appears to be related to several factors. The most important of them are probably ecological and dermatographic changes (Ashford, 1999). The spread of the disease might also be facilitated by increasing urbanization processes in the settlements, that are usually overcrowded and provide inadequate housing and poor sanitations. Human and dog population movement could act as an important risk factor in spread of the disease. In fact, the high risk for L. tropica introduction in southern Italy was related to the importation of infected dogs from northern Africa and the presence of the vector (Gramiccia \& Gradoni, 2005). This might also have lead to the emergence of CL in Chichaoua.

In this study, we showed also that Leishmania DNA could be efficiently extracted and amplified four months old Giemsa stained microscopic slides even these were not protected by a cover slip and contain less than five parasites in each OIF. ITS1-PCR based techniques represent a very sensitive method for the diagnostic of CL from these slides.

Indeed, our result should be considered for the national strategy to control the disease and to evaluate any future potential foci. The identification of L. tropica in cutaneous samples from patients in Chichaoua district is certainly only a first step. Previously, isoenzyme typing (Pratlong et al., 1991; Dereure et 


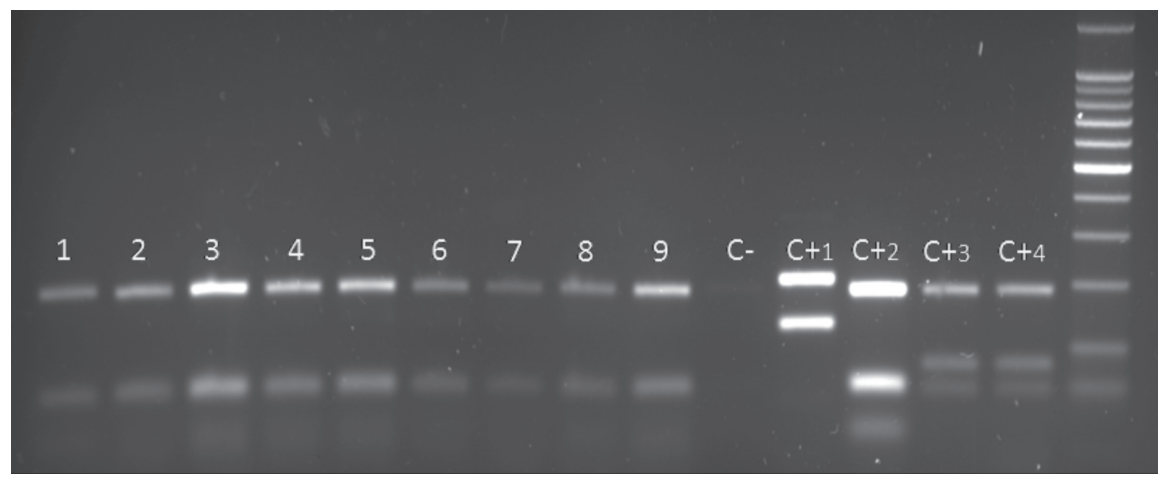

Fig. 1. - Application of RFLP analysis of the ITS1-PCR analysis on positive amastigotes slides from Chichaoua province in 2009.

1-7, samples from slides; C-, negative control; $\mathrm{C}+1$, positive control of L. major (MHOM/IL/1967/Jericho); C+2, positive control of L. tropica (MHOM/AZ/1974/SAF-K27); C+3 and $\mathrm{C}+4$, positive control of $L$. infantum (MHOM/TN/1980/IPT1).

al., 1991) as well as multilocus microsatellite typing (Schwenkenbecher et al., 2006) have shown high genetic diversity of Moroccan strains of L. tropica with different zymodemes/genotypes correlating with anthroponotic and zoonotic transmission cycles of the parasites present in the same CL foci. It should be analyzed next whether the disease in Chichaoua is due to a single or a variety of L. tropica genotypes because that would have consequences for the design of appropriate control measures. Deciphering the transmission factors in an era of climate change will require multicentre and multidisciplinary studies, focusing on reservoir, vectors, therapeutic efficacy, parasite species and strain identification. Local stakeholders and health authorities should be involved in such a network for disease surveillance.

\section{REFERENCES}

Al-Jawabreh A., Schnur L.F., Nasereddin A., Schwenkenbecher J.M., Abdeen Z., Barghuthy F., Khanfar H., Presber W. \& SCHÖNIAN G. The recent emergence of Leishmania tropica in Jericho (A'riha) and its environs, a classical focus of Leishmania major. Trop Med Int Health, 2004, 9, 1-5.

ASHFORD R.W. Cutaneus leishmaniasis control: strategies for prevention. Clinics in Dermatology, 1999, 17, 327-332.

Dereure J., Rioux J.A., Gallego M., Périères J., Pratlong F., MaHJOUR J. \& SADDIKI H. Leishmania tropica in Morocco: infection in dogs. Trans Royal Soc Trop Med Hyg, 1991, 85,595

El Tai N.O., Osman O.F., El Fari M., Presber W. \& Schönian G. Genetic heterogeneity of ribosomal internal transcribed spacer in clinical samples of Leishmania donovani spotted on filter paper as revealed by single-strand conformation polymorphisms and sequencing. Trans Royal Soc Trop Med Hyg, 2000, 94, 575-579.

Guernaoui S., Boumezzough A., Pesson B. \& Pichon G. Entomological investigations in Chichaoua: an emerging epidemic focus of cutaneous leishmaniasis in Morocco. $J$ Med Entomol, 2005, 42 (4), 697-701.
Guessouss-Idrissi N., Chineb S., Hamdani A. et al. Cutaneous leishmaniasis: an emerging epidemic focus of Leishmania tropica in north Morocco. Trans Roy Soc Trop Med Hyg, 1997, 91, 660-663.

Gramiccia M. \& Gradoni L. The current status of zoonotic leishmaniases and approches to disease control. Int $J$ Parasitol, 2005, 35, 1169-1180.

Marty P., Le Fichoux Y., Pratlong F., Rioux J.A., Rostain G. \& LACOUR J.P. Cutaneous leishmaniasis due to Leishmania tropica in a young Moroccan child observed in Nice, France. Trans Roy Soc Trop Med Hyg, 1989, 83, 510.

Meredith S.E.O., Zijlstra E.E., Schoone G.J., Kroon C.C.M., VAn Eys G.J.J.M., Schaeffer K.U., El Hassan A.M. \& LaWyer P.G. Development and application of the polymerase chain reaction for the detection and identification of Leishmania parasites in clinical material. Arch Inst Pasteur Tunis, 1993, 70, 419-431.

Minoubi I., Picot S., Hafirassou N. \& De Monbrison F. Cutaneous leishmaniasis caused by Leishmania tropica in Algeria. Trans Roy Soc Trop Med Hyg, 2008, 102, 11571159.

MinistèRE DE SANTÉ. État d'avancement des programmes de lutte contre les maladies parasitaires. Direction de l'épidémiologie et de lutte contre les maladies, Maroc, 2001.

MinistèRE DE SANTÉ. État d'avancement des programmes de lutte contre les maladies parasitaires. Direction de l'épidémiologie et de lutte contre les maladies, Maroc, 2007.

Pratlong F., Rioux J.A., Dereure J., Mahjour J., Gallego M., Guilvard E., Lanotte G., Perieres J., Martini A. \& Saddiki A. Leishmania tropica au Maroc : diversité isozymique intrafocale. Ann Parasitol Hum Comp, 1991, 66, 100-104.

Rhajaoui M., Nasereddin A., Fellah H., Azmi K., Amarir F., Al-Jawabreh A., Ereqat S., Planer J. \& Abdeen Z. New clinico-epidemiologic profile of cutaneous leishmaniasis, Morocco. Emerg Infect Dis, 2007, 13, 1358-1360.

RhajaOu M. Les leishmanioses humaines au Maroc : une diversité noso-géographique. Pathologie Biologie, 2011, 59, 226-229, doi:10.1016/j.patbio.2009.09.003.

Rioux J.A., Guilvard E., Dereure J., Lanotte G., Denial C., Pratlong C., Serres E \& Belmonte A. Infestation naturelle de Phlebotomus papatasi (Scopoli, 1786) par Leishmania major Mon-25. À propos de 28 souches isolées dans un 
foyer du Sud marocain, in: Leishmania. Taxonomie et phylogenèse. Applications éco-épidémiologiques (Colloque International CNRS/INSERM/OMS, 2-6 juillet 1984). IMEEE, Montpellier, 1986, 471-480.

Schönian G., Nasereddin A., Dinse N., Schweynoch C., Schallig H.D., Presber W. \& Jaffe C.L. PCR diagnosis and characterization of Leishmania in local and imported clinical samples. Diagn Microbiol Infec Dis, 2003, 47, 349-358.

Schwenkenbecher J.M., Wirth T., Schnur L.F., JafFe C.L., Schallig H., Al-Jawabreh A., Hamarsheh O., Azmi K., Pratlong F. \& SchÖnian G. Microsatellite analysis reveals genetic structure of Leishmania tropica. Int J Parasitol, 2006, 36 (2), 237-246.

Received on April 17th 2011 Accepted on September $10^{\text {th }}, 2011$ 